\title{
Olga Anna Dull, Folie amoureuse et politique dans la «Sotise a huit personnaiges» (vers 1507)
}

\section{Maria Colombo Timelli}

\section{(2) OpenEdition}

1 Journals

\section{Édition électronique}

URL : https://journals.openedition.org/studifrancesi/39067

DOI : $10.4000 /$ studifrancesi.39067

ISSN : 2421-5856

Éditeur

Rosenberg \& Sellier

\section{Édition imprimée}

Date de publication : 1 décembre 2004

Pagination : 344

ISSN : 0039-2944

\section{Référence électronique}

Maria Colombo Timelli, « Olga Anna Dull, Folie amoureuse et politique dans la «Sotise a huit

personnaiges» (vers 1507)», Studi Francesi [En ligne], 143 (XLVIII | II) | 2004, mis en ligne le 30 novembre 2015, consulté le 19 mai 2021. URL : http://journals.openedition.org/studifrancesi/39067 ; DOI :

https://doi.org/10.4000/studifrancesi.39067

Ce document a été généré automatiquement le 19 mai 2021.

\section{(c) $($ ) $\odot$}

Studi Francesi è distribuita con Licenza Creative Commons Attribuzione - Non commerciale - Non opere derivate 4.0 Internazionale. 


\title{
Olga Anna Dull, Folie amoureuse et politique dans la «Sotise a huit personnaiges» (vers 1507)
}

\author{
Maria Colombo Timelli
}

\section{RÉFÉRENCE}

OLGA ANNA DULL, Folie amoureuse et politique dans la «Sotise a huit personnaiges» (vers 1507), in Erotica Veterà, Hommage à ROSE M. BIDLER, pp. 31-46 («Le moyen français», 50, 2002).

1 Pièce anonyme d'origine méridionale, cette Sotise conjugue le discours satirique et l'imagination utopique, en mettant en scène, entre autres, une forme primitive de communisme sexuel. O.A.D. se propose, par une analyse du contexte historique et idéologique du début du XVIe siecle, de relever les implications politiques de cette «folie amoureuse» à l'époque du contraste qui opposa Louis XII au pape Jules II. Une telle folie, incarnée par Sotte folle, détruit les conventions et déchaîne l'hérésie. La Sotise se ferait ainsi l'apologie d'un pouvoir centralisé, seul capable de mettre fin aux abus dans tous les domaines. 